Sains Malaysiana 50(3)(2021): 667-676

http://dx.doi.org/10.17576/jsm-2021-5003-09

\title{
Enhanced in vitro Shoot Regeneration and Biochemical Properties of Stevia rebaudiana using Chitosan
}

(Penambahbaikan Penjanaan Semula Pucuk Secara in vitro Serta Sifat Biokimia pada Stevia rebaudiana oleh Kitosan)

\author{
Chu-Nie Tang, Dhilia Udie lamasudin, Wan Muhamad Asrul Nizam Wan Abdullah, Chew-li Moo, \\ MiaO-Si ChiEW, Qian-YeE Chai, Janna OnG-ABDUllaH \& KoK-SONG LaI*
}

\begin{abstract}
Stevia rebaudiana is a herbaceous perennial plant with great global demand due to its beneficial steviol glycosides (SGs) content. Current conventional breeding technique is unable to cater the need for more S. rebaudiana planting materials. Therefore, an improved in vitro shoot regeneration protocol was developed for $\mathrm{S}$. rebaudiana by using chitosan. The highest fresh weight of plant $(0.586 \pm 0.176 \mathrm{~g} /$ explant $)$, dry weight of plant $(0.056 \pm 0.02 \mathrm{~g} /$ explant $)$ and plant height (4.94 $\pm 1.17 \mathrm{~cm} /$ explant) with maximum number of leaves (25.33 \pm 6.95 /explant) were observed on explants grown in optimun treatment of MS basal medium supplemented with $1.0 \mathrm{mg} / \mathrm{L}$ of 6-benzyaminopurine (BAP) and $60 \mathrm{mg} / \mathrm{L}$ of low molecular weight (MW) chitosan after 4 weeks of culture. Scanning electron microscopy (SEM) analysis showed that new shoot primordia and shoot bud formation can be seen as early as day 3 and 5 of cultures on optimun treatment. Further biochemical assays showed that total phenolic acid content, total protein content and total hydrolyzed sugar content were recorded higher in explants cultured in optimun treatment as compared to control media. In contrast, total chlorophyll content and total flavonoids content were reduced in optimum treatment. Meanwhile, no significant difference in antioxidant activity was observed. All cultures from the optimal treatment were successfully regenerated, acclimatized and grew well with 100\% survival rate. Taken together, an enhanced and efficient shoot regeneration protocol of S. rebaudiana was successfully developed which will be useful for rapid and large-scale micropropagation in future.
\end{abstract}

ABSTRACT

Keywords: Chitosan; micropropagation; scanning electron microscope (SEM); stevia; tissue culture

\section{ABSTRAK}

Stevia rebaudiana ialah sejenis tumbuhan herba saka yang mempunyai permintaan antarabangsa yang tinggi dengan kandungan steviol glikosid (SGs) yang berfaedah. Kaedah biakbaka konvensional tidak dapat memenuhi permintaan anak pokok S. rebaudiana yang semakin meningkat. Oleh itu, satu protokol penambahbaikan penjanaan semula pucuk $\mathrm{S}$. rebaudiana secara in vitro dengan menggunakan kitosan telah dibangunkan. Tumbuhan dengan berat basah maksimum $(0.586 \pm 0.176$ g/eksplan), berat kering maksimum $(0.056 \pm 0.02$ g/eksplan), ketinggian maksimum $(4.94 \pm 1.17 \mathrm{~cm} /$ eksplan) dan bilangan daun tertinggi (25.33 \pm 6.95 leksplan) telah diperhatikan dalam media bes MS yang ditambah dengan $1.0 \mathrm{mg} / \mathrm{L}$ 6-benzilaminopurina (BAP) yang ditambah dengan kitosan berat molekul (MW) rendah, $60 \mathrm{mg} / \mathrm{L}$, selepas 4 minggu dari tempoh kultur. Analisis mikroskop elektron pengimbas (SEM) telah menunjukkan pertumbuhan pucuk primordium baru serta tunas pucuk telah wujud seawal 3 hari dan 5 hari selepas rawatan optimum kitosan. Selanjutnya, asai biokimia telah menunjukkan bahawa kandungan jumlah asid fenolik, kandungan protein dan kandungan gula terhidrolisis adalah lebih tinggi di dalam eksplan yang tumbuh di dalam media optimum berbanding dengan media kawalan. Namun begitu, kandungan klorofil dan flavonoid di dalam eksplan adalah berkurangan dalam media optimum. Tiada perbezaan ketara dapat dilihat di dalam kandungan antioksidan. Semua kultur daripada rawatan optimum telah berjaya ditumbuh semula, diaklimitasi dan tumbuh dengan sihat pada kadar kelangsungan hidup 100\%. Kesimpulannya, satu protokol penjanaan semula S. rebaudiana yang ditambahbaik serta berkesan telah berjaya dibangunkan dan berguna untuk pembiakan dengan cepat dan besar-besaran pada masa hadapan.

Kata kunci: Kitosan; kultur tisu; mikroperambatan; mikroskop elektron pengimbas (SEM); stevia 


\section{INTRODUCTION}

Stevia rebaudiana is a perennial herb that belongs to the Asteraceae family and originated from northern regions of South America (Chiew et al. 2019). The leaves are rich with sweetening agents known as SGs, which are estimated to be 100 - 300 times sweeter than sucrose. SGs are mainly composed of stevioside and rebaudioside A (Reb-A) (Chiew et al. 2016; Gauchan et al. 2014). Over the years, the demand for $S$. rebaudiana has been increasing rapidly in the global market (Future Market Insights 2014). This is because SGs are zero in calories and suitable to be consumed by diabetes patient (Ummi et al. 2014). Hence it can be widely used to replace artificial sweetening agent in food and beverage industry.

In general, S. rebaudiana plantlet is propagated through conventional plant breeding including stem cutting, seedling and cross-pollination methods. However, these conventional methods are low in germination rate (below $10 \%$ ), slow in regeneration efficiency, and higher variation in offspring (Tadhani et al. 2006; Ummi et al. 2014). Often, seed germination does not produce a homogenous population of offsprings, resulting in variations in SGs level and composition. In addition, the qualities of the plantlets produced are unstable and variable. Most importantly, conventional methods rely heavily on human capitals for stem cutting and maintaining. Thus, an alternative route for propagation of $S$. rebaudiana is through in vitro micropropagation techniques. Several studies had reported the use of vegetative tissues such as nodal segment and axillary bud (Das et al. 2011), shoot (Ummi et al. 2014), and hypocotyl (Ramírez-Mosqueda \& Iglesias-Andreu 2016) for in vitro micropropagation of $S$. rebaudiana. Despite these reported studies, there is a need to improve the existing formulation for more efficient micropropagation of $S$. rebaudiana. This is because the efficiency of in vitro micropropagation is greatly influenced by factors such as plant genotypes, type of explant, medium composition, and growth additives.

Chitosan is a growth enhancer, widely used in agricultural industry. It is a biopolymer deacetylated form of chitin (poly [ $\beta$-(1->4)-2-amino-2-deoxy-Dglucopyranose]) that present in outer shell of organisms, such as shrimp, crab, and crustaceans (Chawla et al. 2015). Chitosan is bio-degradable, safe, and environmental friendly. Generally, chitosan can be divided into low (50 - $190 \mathrm{kDa})$, medium (190 - $310 \mathrm{kDa}$ ) and high molecular weight (MW) (310 - $375 \mathrm{kDa})$ with a deacetylation degree of 75 - 85\% (Grobler \& Perchyonok 2018). Low MW chitosan shows higher solubility and low viscosity in water at physiologically acceptable $\mathrm{pH}$ values as compared to medium and high MW chitosans. Previously, chitosan had been reported to use as growth enhancer in plant species such as Oryza sativa (Chamnanmanoontham et al. 2015) and orchid (Pornpienpakdee et al. 2010; Sopalun et al. 2010). Besides, chitosan also used to enhance secondary metabolite production in ginseng (Jeong \& Park 2005) and Psoralea corylifolia (Ahmed \& Baig 2014). In addition, it also enhances plant disease resistance towards pathogens attack (Uthairatanakij et al. 2007) and various environmental stresses (El Hadrami et al. 2010). However, the efficiency of chitosan is greatly dependent on the type and concentration used (Sivanandhan et al. 2013). Therefore, a proper optimization and manipulation of chitosan are required in order to achieve the desire outcomes.

To date, the effects of chitosan on $S$. rebaudiana regeneration remain largely unknown despite it has been proven to be effective in other plant species. Hence, the aim of this study was to enhance the shoot regeneration protocol of $S$. rebaudiana through optimization of suitable types and concentration of chitosan used. Furthermore, biochemical properties of $S$. rebaudiana cultured on control and optimum treatment media were also analyzed. Ultimately, the improved shoot regeneration protocol with growth enhancer can be used to speed up the mass micropropagation of $S$. rebaudiana.

\section{Materials AND Methods}

\section{PLANT MATERIALS PREPARATION}

One month old potted $S$. rebaudiana plant was bought from Jacky Lim Nursery, Sungai Buloh, Malaysia (3.223257, 101.589001). Young shoot tips were collected and nodes measuring $2 \mathrm{~cm}$ were chosen as explants from potted $S$. rebaudiana plant. Explants were cut and washed thoroughly under running tap water containing two drops of surfactant Tween-20 solution for $15 \mathrm{~min}$. In aseptic condition, the explants were surfaced sterilized with $70 \%(\mathrm{v} / \mathrm{v})$ ethanol for $3 \mathrm{~min}$ and rinsed with sterilized distilled water for $3-5 \mathrm{~min}$, followed by $10 \%(\mathrm{v} / \mathrm{v})$ chlorox solution for $15 \mathrm{~min}$ and rinsed with distilled water again. Explants were dried with sterile blotting paper and cut into $2 \mathrm{~cm}$ in sterilized petri dish.

\section{MEDIA PREPARATION ON SHOOT INDUCTION}

Excised explants of $S$. rebaudiana were transferred and cultured on Murashige and Skoog (MS) basal medium (Murashige \& Skoog 1962) supplemented with $30 \mathrm{~g} / \mathrm{L}$ sucrose and solidified with $7.5 \mathrm{~g} / \mathrm{L}$ of agar (Gelrite) and incorporated with $1 \mathrm{mg} / \mathrm{L}$ 6-benzylaminopurine (BAP). The $\mathrm{pH}$ of the medium was adjusted to 5.70 with 0.1 $\mathrm{M} \mathrm{NaOH}$ or $\mathrm{HCl}$ before autoclaving at $121{ }^{\circ} \mathrm{C}$ for 15 min. The cultures were incubated at $24 \pm 2{ }^{\circ} \mathrm{C}$ with a 
$16 \mathrm{~h}$ photoperiod. The regenerated shoots were cut and individual shoots were place on MS medium supplemented with $1 \mathrm{mg} / \mathrm{L}$ BAP for further multiple shoots induction.

\section{CHITOSAN TREATMENT}

Nodal explants from four weeks old $S$. rebaudiana shoot tips $(\sim 1 \mathrm{~cm})$ cultured from MS medium supplemented with $1.0 \mathrm{mg} / \mathrm{L}$ BAP were cut and individual explant was cultured on MS medium containing different MW (low, medium and high) and concentration $(0,20,40,60$, 80 , and $100 \mathrm{mg} / \mathrm{L})$ of chitosan supplemented with 1.0 $\mathrm{mg} / \mathrm{L}$ of BAP. Excised explants cultured on MS medium supplemented with $1.0 \mathrm{mg} / \mathrm{L}$ of BAP only (without chitosan) was used as control. Data for plant height, number of leaves, fresh weight (FW) and dry weight (DW) for all treatments were collected at four week-old culture.

\section{SEM}

For scanning electron microscope examination, day 3 and day $5 S$. rebaudiana samples cultured in optimum concentration of chitosan medium were used. Scanning electron microscopy was carried out according to protocol by Lai et al. (2011) with slight modifications. Firstly, samples were cut into $1 \mathrm{~cm}^{3}$ slices and put into separate vials according to different day of culture. Then, samples were fixed in fixative which contained $4 \%$ glutaraldehyde for 2 days. After 2 days of primary fixation, samples were washed with $0.1 \mathrm{M}$ sodium cacodylate buffer for 3 times of $30 \mathrm{~min}$ each and post-fixed in 1\% osmium tetroxides for $2 \mathrm{~h}$ at $4{ }^{\circ} \mathrm{C}$. Next, samples were washed again with $0.1 \mathrm{M}$ sodium cacodylate buffer for 3 times (30 min each) before dehydration process was done. After fixation and washing process was done, samples were subsequently dehydrated in a series of acetone (35, 50,75 , and $95 \%$ once for 30 to $45 \mathrm{~min}$ at each step, and then immersed in 100\% of acetone thrice for $1 \mathrm{~h}$ each). Then, the samples were transferred from absolute acetone to critical point drying apparatus. By using critical point drying (CPD) method, specimens were transferred into specimen basket and put into critical dryer for half an hour. Specimens dried by CPD method were transferred and mounted to specimen stub using colloidal silver. A number of gold layers were coated over the specimen to increase the conductivity of the secondary electrons. After the coating process, specimens were observed under scanning electron microscope (JEOL JSM-600, Japan) in Institute of Bioscience (IBS), Universiti Putra Malaysia (UPM).

\section{REGENERATION OF $S$. rebaudiana}

Four weeks old of well-grown $S$. rebaudiana explant cultured at optimum media was transferred to rooting media with MS basal medium supplemented with 0.4 $\mathrm{mg} / \mathrm{L}$ of NAA growth regulator (Thiyagarajan \& Venkatachalam 2012). After 3 weeks of rooting treatment, well-rooted plantlet with multiple shoot was acclimatized and transferred to pot with sand and soil (1:1) for adaptation.

\section{BIOCHEMICAL ASSAY ANALYSIS}

Biochemical assays were carried out using leaves of 4 weeks old $S$. rebaudiana cultured on MS medium supplemented with $1.0 \mathrm{mg} / \mathrm{L}$ of BAP (Control) and optimum treatment media (MS medium supplemented with $1.0 \mathrm{mg} / \mathrm{L} \mathrm{BAP}$ and $60 \mathrm{mg} / \mathrm{L}$ of low MW chitosan). Biochemical assay performed included total chlorophyll assay (Talreja 2011); total phenolic acid assay (John et al. 2014); total flavonoid assay (John et al. 2014); total hydrolysed sugar assay (Van Handel 1985); total protein assay (Bradford 1976) and DPPH radical scavenging assay (Büyüktuncel et al. 2014).

\section{STATISTICAL ANALYSIS}

Each of the growth parameters were carried out in triplicates with 3 samples per replicate. Data were analyzed using one-way ANOVA (analysis of variance) in a completely randomized design. The differences among means were determined by S-N-K (Student-NewmanKeuls) Test at 95\% significance level. Similarly, each of the biochemical assay experiment was carried out in triplicates. Data were analyzed using independent sample of T-test in a completely randomized design. All statistical analyses were performed at $95 \%(\mathrm{p} \leq 0.05)$ significant level using SPSS (SPSS Inc. USA version 24).

\section{RESULTS AND DisCUSSION}

\section{EFFECT OF CHITOSAN ON SHOOT REGENERATION}

Previous studies had shown that chitosan can act as growth enhancer in plant due to its ability as an elicitor which could stimulate the production of endogenous phytohormone (Chamnanmanoontham et al. 2015). However, usage of chitosan as a growth enhancer should be studied properly because its efficiency is known to be highly dependent towards plant species, concentration and molecular weight (Dzung et al. 2017; Singh 2016). In our study, $60 \mathrm{mg} / \mathrm{L}$ low $\mathrm{MW}$ chitosan was found to be the optimum treatment in promoting the growth of $S$. rebaudiana (Figure 1). In MS media supplemented with $60 \mathrm{mg} / \mathrm{L}$ of low MW of chitosan, the highest plant height $(4.94 \mathrm{~cm})$, number of leaves $(25.33)$, fresh weight $(0.586$ g) and dry weight $(0.056 \mathrm{~g})$ were recorded (Figure 1). Optimum concentration (60 mg/L of low MW of chitosan) 
also induced early leaf formation which could be seen on the week 1 (Figure 3(c)). According to Rahman et al. (2018), chitosan could speed-up the formation of leaf due to changes in programming of protein metabolism in plant growth. Application of chitosan will promote the number of leaf formation had also been reported in the works done by Agbodjato et al. (2016) and Mondal et al. (2013) on maize plants. Their results showed that increasing concentration of chitosan increased the number of leaves until optimum concentration is achieved. However, other concentrations $(20,40,80$, and $100 \mathrm{mg} / \mathrm{L})$ were not significantly enchanced the growth parameters of $S$. rebaudiana (Figure 1). High concentration of chitosan (80 and $100 \mathrm{mg} / \mathrm{L}$ ) showed significant inhibition of the plant growth. This could be due to high concentration of chitosan, which is harmful to the plant (Singh 2016). Similarly, Asghari-Zakaria et al. (2009) also reported that high concentration of chitosan used in potato would eventually inhibit the plant growth. In addition, our study demonstrated that high MW of the chitosan resulted in distortion of leaf development (curly leaves) as shown in Figure S1. On the other hand, low concentrations of chitosan (20 and $40 \mathrm{mg} / \mathrm{L}$ ) were found to be insufficient to induce the plant growth signalling pathway which will not enhance plant growth (Singh 2016).

\section{SEM ON SHOOT BUD FORMATION}

SEM was used to further observe the morphological changes and formation of shoot bud at the stem nodal culture on optimum treatment media $(60 \mathrm{mg} / \mathrm{L}$ of low MW chitosan). SEM image showed that there was a formation of new shoot primordia in the culture sample which gave rise to shoot formation on day 3 of culture (Figure 2). Formation of new shoot primordia in a short period of time indicates a good regeneration efficiency of shoot bud in stevia plants. This result was positively correlated with the work done by San José et al. (2014) which showed that formation of shoot primordia was due to cell division and led to cell differentiation. Meanwhile, SEM image of day 5 culture sample with optimum treatment (Figure 2(b) 2(d)) showed formation of shoot bud. The shoot primordia form shoot bud which will then give rise to shoot and leaf formation in the explant.

\section{REGENERATION OF S. rebaudiana}

A well regenerated potted $S$. rebaudiana was observed after 4 weeks of acclimatization in pot (Figure 3). In this study, we successfully regenerated $S$. rebaudiana in 3 months by using chitosan as an enhancer. Similar works done by Thiyagarajan and Venkatachalam (2012) on regeneration on $S$. rebaudiana without using growth enhancer took approximately 4 months. Thus, mass propagation of $S$. rebaudiana with addition of chitosan as growth enhancer is recommended in order to shorten its regeneration time.

\section{BIOCHEMICAL ASSAYS}

The plant growth can be determined by total chlorophyll content as it is linked with the production of food sources in plant via photosynthesis (Muley et al. 2019). However, our study showed that total chlorophyll content in S. rebaudiana explant using control media was 55\% higher than in optimum treatment media (Figure 4(a)). As reported previously, no significant difference in chlorophyll content was observed in okra plants treated with chitosan (Bistgani et al. 2017a; Mondal et al. 2012). It was suggested that the chitosan may not have direct effects on the total chlorophyll content, but it enhanced the photosynthetic activity which was driven by upregulated expression level of rubisco in carbon fixation (Zhang et al. 2017). In addition, SGs are synthesized via methylerthritol phosphate (MEP) pathway which also involved synthesis of chlorophyll pigments (Kumar et al. 2012; Totté et al. 2000). This suggests that there will be competition in energy consumptions between SGs synthesis and chlorophyll synthesis. Another study done by Zheng et al. (2019) on overexpression of MEP pathway responsive gene, $S r D X S$ in $S$. rebaudiana plant also resulted in no difference in chlorophylls and carotenoids levels, suggesting that excess precursors from MEP pathway may divert biosynthesis on other secondary metabolites instead of chlorophylls. Therefore, similar activity may be applied in this study.

The total hydrolyzed sugar contents recorded in optimum treatment $(0.102 \mathrm{mg} / \mathrm{g})$ was significantly higher compared to control $(0.077 \mathrm{mg} / \mathrm{g}$ ) (Figure $4(\mathrm{~b}))$. This result was in-line with the works done by He et al. (2018) and Zou et al. (2015) on strawberry and maize plants. In addition, study done by Chamnanmanoontham et al. (2015) also showed altered expression of carbohydrate metabolism in rice due to chitosan treatment via increased expression level of glyceraldehyde-3-phosphate dehydrogenase, enolase, and phosphoglucomutase which indicate higher energy production level in rice. Thus, plant growth enhancer by chitosan might involve in regulation of carbon metabolism which lead to sugar accumulation (Chamnanmanoontham et al. 2015; Zhang et al. 2017). As reported previously, derivatives of sugar is important as a precursor in SGs biosynthesis pathways (Ceunen \& Geuns 2013; Yoneda et al. 2017). In addition, Sun et al. (2019) reported that increased of sugar accumulation lead to enhance of SGs production. Hence, $60 \mathrm{mg} / \mathrm{L}$ of low MW chitosan treatment could stimulate SGs production in $S$. rebaudiana. 
On the other hand, the protein concentration in $S$. rebaudiana plantlets grown in optimum treatment was higher compared to control treatment (Figure 4(c)). The result was similar with the study recorded by Anusuya and Sathiyabama (2016) on effect of chitosan on turmeric plants. As reported previously, chitosan could increase the protein content in the plant via enhancement of nitrogen and carbon assimilation (Zhang et al. 2017). The protein could be used to enhance plant metabolism for growth improvement (Suriyaprabha et al. 2017).

Phenolics are recognised as the largest phytochemicals that play an important role in plant defense mechanism against biotic and abiotic stresses (Samanta et al. 2011). Most of the phenolic compounds found in plants can be classified into phenolic acids while flavonoids (Hannan et al. 2016). Phenolic compounds also show antioxidant activity in plant (Rahman et al. 2018; Shukla et al. 2009). In this study, $60 \mathrm{mg} / \mathrm{L}$ of low MW chitosan had caused reduction in flavonoids while antioxidants content remained unchanged in $S$. rebaudiana (Figure 4(e) - 4(f)). However, $13 \%$ increment of phenolic acid was observed in chitosan treated plant (Figure 4(d)). As reported previously, chitosan treatment could impose additional stress to the plant (Lopez-Moya et al. 2017). Upon stress induction, plants are required to produce more phenolic compounds to maintain the cellular homeostasis (Jamalian et al. 2013).
In this study, it was found that the signalling pathway of phenolic acid was activated to counteract with the stress imposed by chitosan in S. rebaudiana. With the presence of phenolic acids to counteract with the stress, excessive free radicals will no longer be produced. Thus, the antioxidant capacity remained unchanged between control and chitosan treated plants. Other studies done by Hajihashemi and Geuns (2013) and Shukla et al. (2009) also suggested that phenolics compound may be the major contributors to antioxidants activity in $S$. rebaudiana. In addition, works done by Álvarez-Robles (2016) also suggesting that phenols biosynthesis pathway of $S$. rebaudiana will lead more on production of hydroxycinnamic acid derivatives than flavonoids production. Previous study done on thyme plants with chitosan treatment also showed similar result in which phenolic content was increased while flavonoids content remains almost unchanged (Bistgani et al. 2017b). Rahman et al. (2018) also reported that chitosan treatment successfully induced the production of phenolic acid in strawberry plants. Increased of phenolic acid together with enhanced plant growth supported the alternative concept on interlinked processes between growth and immunity instead of trade off relationship between plant growth and immunity (Kliebenstein 2016; Rahman et al. 2018).
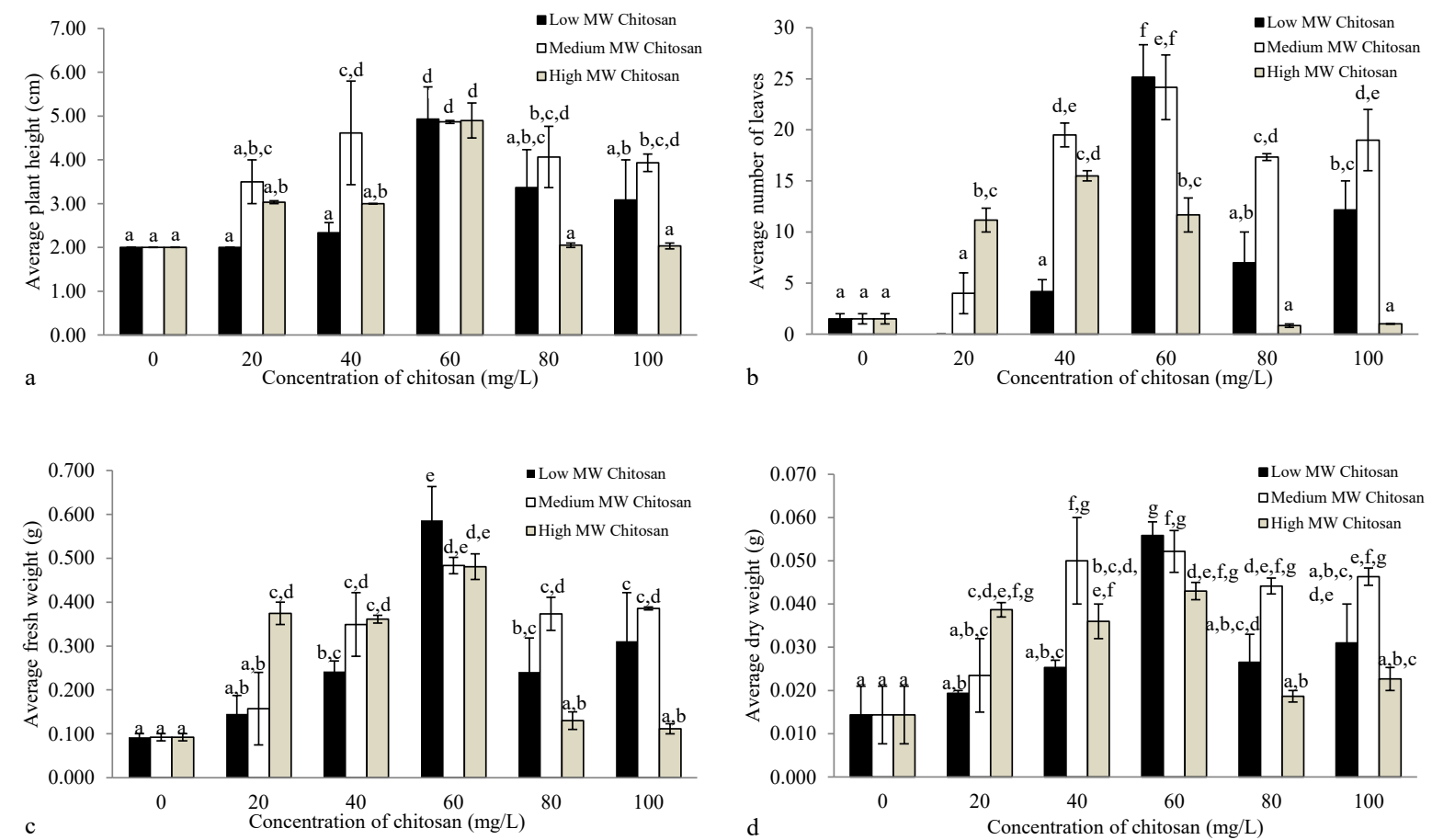

FIGURE 1. Effect of different types and concentrations of chitosan on (a) average plant height, (b) average number of leaves produced, (c) average fresh weight, and (d) average dry weight of $S$. rebaudiana explant. All results were obtained after 4 weeks of culture. Result indicates the mean ( \pm SE) of 3 independent experiments with 3 replicates for each treatment. Bars with different letters represent significant difference at $\mathrm{P} \leq 0.05$ 

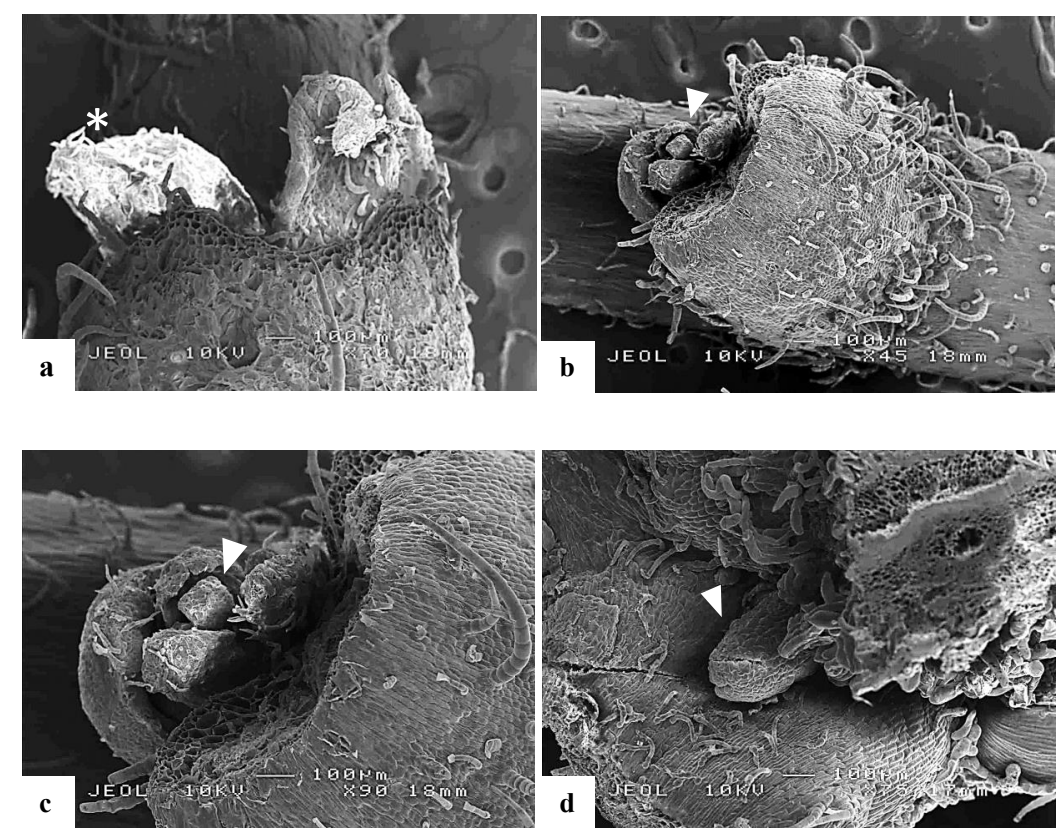

FIGURE 2. SEM observation on formation of shoot bud using optimum concentration $60 \mathrm{mg} / \mathrm{L}$ of low MW chitosan on the in vitro growth of S. rebaudiana using shoot explants after 3 days and 5 days culture sample: (a) SEM image of day 3 culture sample, and (b - d) SEM image of day 5 culture sample. White asterisk represents formation of new shoot primordia while white arrow represents formation of shoot bud

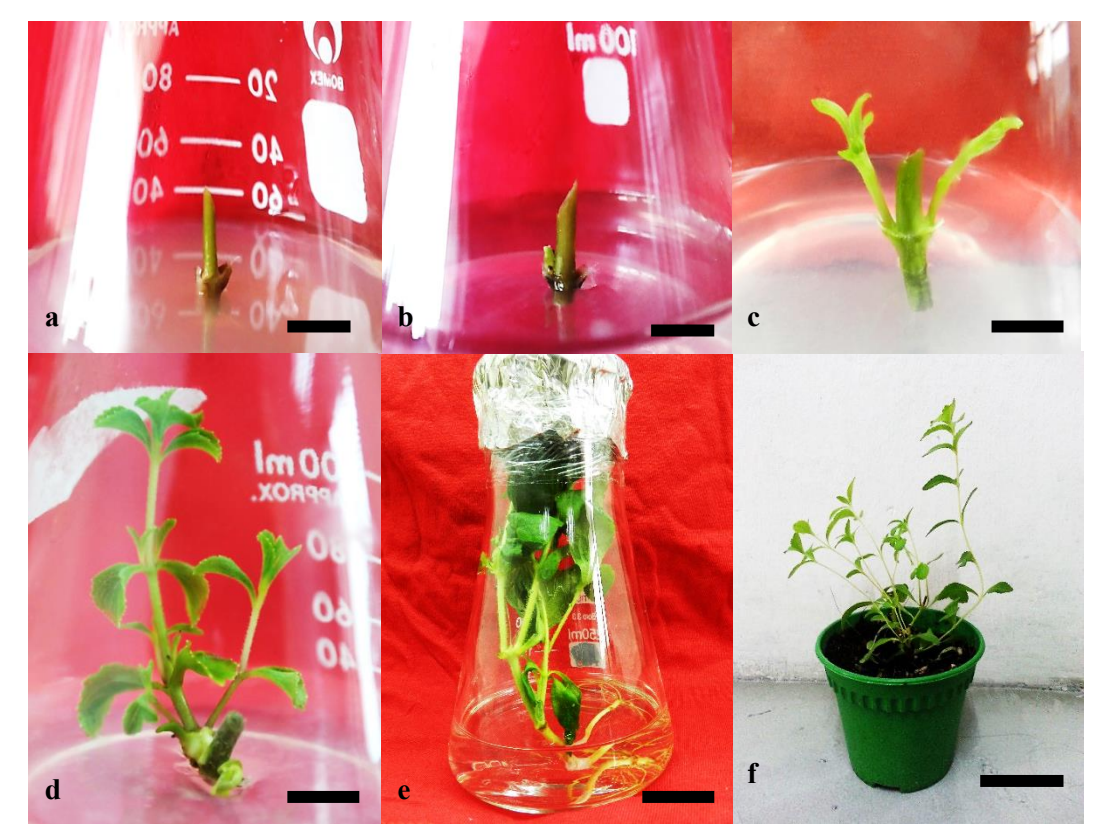

FIGURE 3. Stages of in vitro plant regeneration of S. rebaudiana: (a) initiation (day 0 ) of S. rebaudiana stem nodal culture, (b) shoot bud formation after 5 days of culture in MS basal medium with $1.0 \mathrm{mg} / \mathrm{L}$ of BAP hormone and supplemented with $60 \mathrm{mg} / \mathrm{L}$ of low MW chitosan, (c) leaves formation after 1 week of culture in MS basal medium with $1.0 \mathrm{mg} / \mathrm{L}$ of BAP hormone and supplemented with $60 \mathrm{mg} / \mathrm{L}$ of low MW of chitosan, (d) development of shoots after 4 weeks of culture, (e) development of root of in vitro $S$. rebaudiana explant using root medium after 3 weeks of culture, and (f) well-grown regenerated $S$. rebaudiana plant after 4 weeks of planting. Bar a-e $=1 \mathrm{~cm}$ each, $\mathrm{f}=5 \mathrm{~cm}$ 

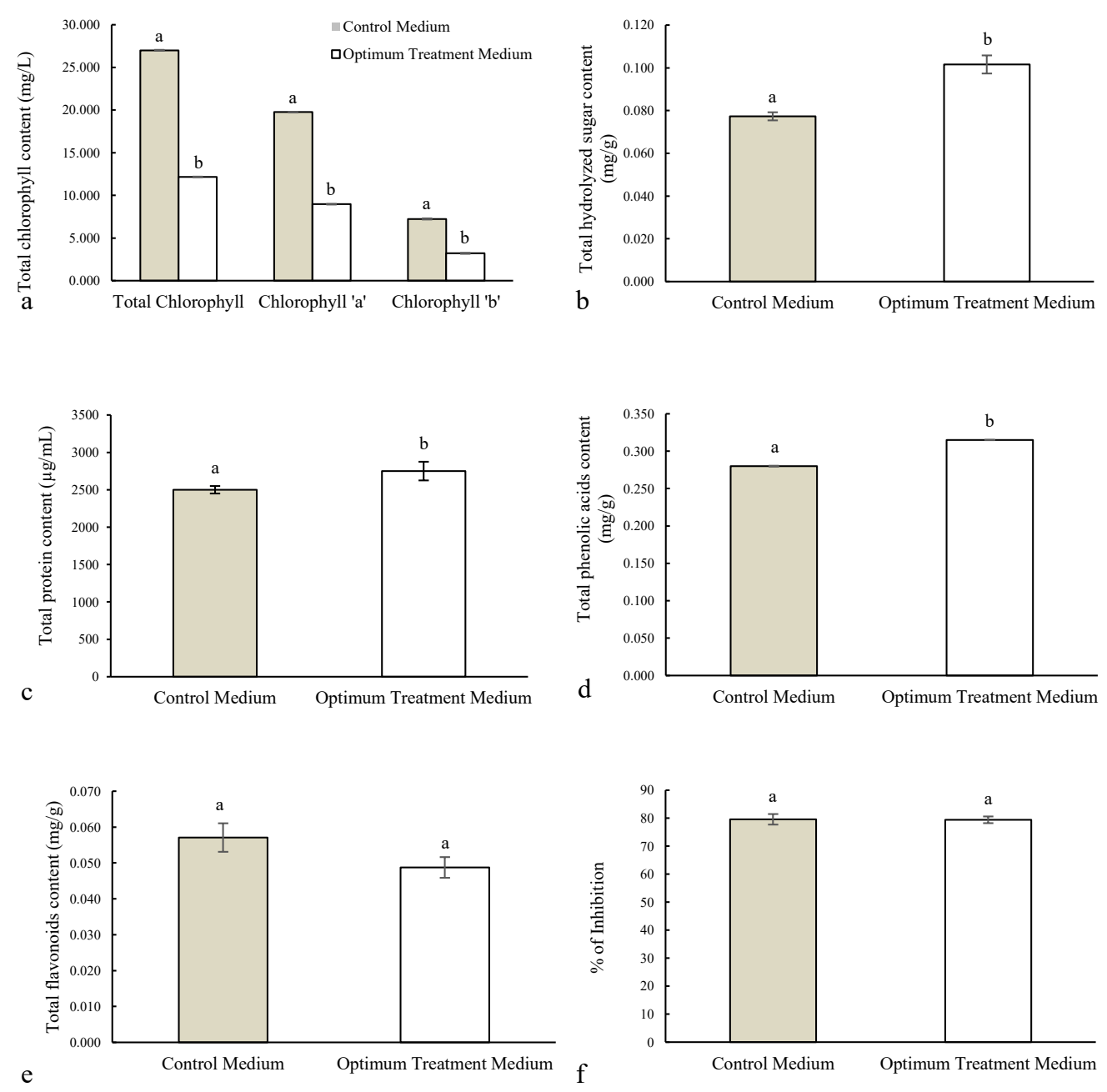

FIGURE 4. Effects on biochemical assays between control and optimum ( $60 \mathrm{mg} / \mathrm{L}$ of low MW chitosan) treatment medium of 4 weeks-old $S$. rebaudiana culture: (a) total chlorophyll content, (b) total hydrolyzed sugar content, (c) total protein content, (d) total phenolic acids content, (e) total flavonoids content, and (f) percentage of inhibition (DPPH free radical scavenging). Result indicates the mean SE ( \pm SE) of 3 independent experiments with 3 replicates for each treatment. Bars with different letters represent significant difference at $\mathrm{P} \leq 0.05$

\section{CONCLUSION}

An improved in vitro $S$. rebaudiana shoot regeneration protocol has been successfully established by using 60 $\mathrm{mg} / \mathrm{L}$ of low MW of chitosan. Chitosan also able to enhance the production of proteins and hydrolysed sugars which will lead to better plant growth.

\section{ACKNOWLEDGEMENTS}

The authors are thankful to Universiti Putra Malaysia for funding this project under Geran Inisiatif Putra Berkumpulan (GP-1PB/2016/9490300) and Putra Grant (GP-IPS/2017/9572400).

\section{REFERENCES}

Agbodjato, N.A., Noumavo, P.A., Adjanohoun, A., Agbessi, L. \& Baba-Moussa, L. 2016. Synergistic effects of plant growth promoting rhizobacteria and chitosan on in vitro seeds germination, greenhouse growth, and nutrient uptake of maize (Zea mays L.). Biotechnology Research International 2016: 1-11.

Ahmed, S.A. \& Baig, M.M.V. 2014. Biotic elicitor enhanced production of psoralen in suspension cultures of Psoralea corylifolia L. Saudi Journal of Biological Sciences 21(5): 499-504.

Álvarez-Robles, M.J., López-Orenes, A., Ferrer, M.A. \& Calderón, A.A. 2016. Methanol elicits the accumulation 
of bioactive steviol glycosides and phenolics in Stevia rebaudiana shoot cultures. Industrial Crops and Products 87: 273-279.

Anusuya, S. \& Sathiyabama, M. 2016. Effect of chitosan on growth, yield and curcumin content in turmeric under field condition. Biocatalysis and Agricultural Biotechnology 6: 102-106.

Asghari-Zakaria, R., Maleki-Zanjani, B. \& Sedghi, E. 2009. Effect of in vitro chitosan application on growth and minituber yield of Solanum tuberosum L. Plant, Soil and Environment 55(6): 252-256.

Bistgani, Z.E., Siadat, S.A., Bakhshandeh, A., Pirbalouti, A.G. \& Hashemi, M. 2017a. Interactive effects of drought stress and chitosan application on physiological characteristics and essential oil yield of Thymus daenensis Celak. The Crop Journal 5(5): 407-415.

Bistgani, Z.E., Siadat, S.A., Bakhshandeh, A., Pirbalouti, A.G. \& Hashemi, M. 2017b. Morpho-physiological and phytochemical traits of (Thymus daenensis Celak.) in response to deficit irrigation and chitosan application. Acta Physiologiae Plantarum 39(10): 231-244.

Bradford, M.M. 1976. A rapid and sensitive method for the quantitation of microgram quantities of protein utilizing the principle of protein-dye binding. Analytical Biochemistry 72(1-2): 248-254.

Büyüktuncel, E., Porgal1, E. \& Çolak, C. 2014. Comparison of total phenolic content and total antioxidant activity in local red wines determined by spectrophotometric methods. Food and Nutrition Sciences 5(17): 1660.

Ceunen, S. \& Geuns, J.M.C. 2013. Glucose, sucrose, and steviol glycoside accumulation in Stevia rebaudiana grown under diferent photoperiods. Biologia Plantarum 57(2): 390-394.

Chamnanmanoontham, N., Pongprayoon, W., Pichayangkura, R., Roytrakul, S. \& Chadchawan, S. 2015. Chitosan enhances rice seedling growth via gene expression network between nucleus and chloroplast. Plant Growth Regulation 75(1): 101-114.

Chawla, S.P., Kanatt, S.R. \& Sharma, A.K. 2015. Chitosan. In Polysaccharides: Bioactivity and Biotechnology, edited by Ramawat, K.G. \& Mérillon, J.M. Switzerland: Springer. pp. 219-246.

Chiew, M.S., Lai, K.S., Hussein, S. \& Abdullah, J.O. 2016. A review on induced mutagenesis of Stevia rebaudiana bertoni. Pertanika Journal of Scholarly Research Reviews 2(3): 77-85.

Chiew, M.S., Lai, K.S., Hussein, S. \& Abdullah, J.O. 2019. Acute gamma irradiated Stevia rebaudiana Bertoni enhanced particular types of steviol glycosides. Asia-Pacific Journal of Molecular Biology and Biotechnology 27(1): 56-65.

Das, A., Gantait, S. \& Mandal, N. 2011. Micropropagation of an elite medicinal plant: Stevia rebaudiana Bert. International Journal of Agricultural Research 6(1): 40-48.

Dzung, P.D., Phu, D.V., Du, B.D., Ngoc, L.S., Duy, N.N., Hiet, H.D., Nghia, D.H., Thang, N.T., Le, B.V. \& Hien, N.Q. 2017. Effect of foliar application of oligochitosan with different molecular weight on growth promotion and fruit yield enhancement of chili plant. Plant Production Science 20(4): 389-395
El Hadrami, A., Adam, L.R., El Hadrami, I. \& Daayf, F. 2010. Chitosan in plant protection. Marine Drugs 8(4): 968-987.

Future Market Insights. 2014. Stevia Market: Global Industry Analysis and Opportunity Assessment 2014-2020. http:// www.futuremarketinsights.com/reports/global-stevia-market.

Gauchan, D.P., Dhakal, A., Sharma, N., Bhandari, S., Maskey, E., Shrestha, N., Gautam, R., Giri, S. \& Gurung, S. 2014. Regenerative callus induction and biochemical analysis of Stevia rebaudiana Bertoni. Journal of Advanced Laboratory Research in Biology 5(3): 41-45.

Grobler, S.R. \& Perchyonok, V. 2018. Cytotoxicity of low, medium and high molecular weight chitosan's on balb/c 3 t 3 mouse fibroblast cells at a $75-85 \%$ de-acetylation degree. Material Science and Engineering with Advanced Research 2(2): 27-30.

Hajihashemi, S. \& Geuns, J.M.C. 2013. Free radical scavenging activity of steviol glycosides, steviol glucuronide, hydroxytyrosol, metformin, aspirin and leaf extract of Stevia rebaudiana. Free Radicals Antioxidants 3: 34-41.

Hannan, P.A., Khan, J.A., Ullah, I. \& Ullah, S. 2016. Synergistic combinatorial antihyperlipidemic study of selected natural antioxidants: Modulatory effects on lipid profile and endogenous antioxidants. Lipids in Health and Disease 15(1): 151-161.

He, Y., Bose, S., Wang, W., Jia, X., Lu, H. \& Yin, H. 2018. Preharvest treatment of chitosan oligosaccharides improved strawberry fruit quality. International Journal of Molecular Sciences 19(8): 2194-2207.

Jamalian, S., Gholami, M. \& Esna-Ashari, M. 2013. Abscisic acidmediated leaf phenolic compounds, plant growth and yield is strawberry under different salt stress regimes. Theoretical and Experimental Plant Physiology 25(4): 291-299.

Jeong, G.T. \& Park, D.H. 2005. Enhancement of growth and secondary metabolite biosynthesis: Effect of elicitors derived from plants and insects. Biotechnology and Bioprocess Engineering 10(1): 73-77.

John, B.I.J.U., Sulaiman, C.T., George, S. \& Reddy, V.R.K. 2014. Total phenolics and flavonoids in selected medicinal plants from Kerala. International Journal of Pharmacy and Pharmaceutical Sciences 6(1): 406-408.

Kliebenstein, D.J. 2016. False idolatry of the mythical growth versus immunity tradeoff in molecular systems plant pathology. Physiological and Molecular Plant Pathology 95: 55-59.

Kumar, H., Kaul, K., Bajpai-Gupta, S., Kaul, V.K. \& Kumar, S. 2012. A comprehensive analysis of fifteen genes of steviol glycosides biosynthesis pathway in Stevia rebaudiana (Bertoni). Gene 492(1): 276-284.

Lai, K.S., Yusoff, K. \& Maziah, M. 2011. Extracellular matrix as the early structural marker for Centella asiatica embryogenic tissues. Biologia Plantarum 55(3): 549-553.

Lopez-Moya, F., Escudero, N., Zavala-Gonzalez, E., EsteveBruna, D., Blázquez, M.A., Alabadi, D. \& Lopez-Llorca, L.V. 2017. Induction of auxin biosynthesis and WOX5 repression mediate changes in root development in Arabidopsis exposed to chitosan. Scientific Reports 7(1): 16813. 
Mondal, M.M.A., Puteh, A.B., Dafader, N.C., Rafii, M.Y. \& Malek, M.A. 2013. Foliar application of chitosan improves growth and yield in maize. Journal of Food, Agriculture and Environment 11: 520-523.

Mondal, M.M.A., Malek, M.A., Puteh, A.B., Ismail, M.R., Ashrafuzzaman, M. \& Naher, L. 2012. Effect of foliar application of chitosan on growth and yield in okra. Australian Journal of Crop Science 6(5): 918-921.

Muley, A.B., Shingote, P.R., Patil, A.P., Dalvi, S.G. \& Suprasanna, P. 2019. Gamma radiation degradation of chitosan for application in growth promotion and induction of stress tolerance in potato (Solanum tuberosum L.). Carbohydrate Polymers (210): 289-301.

Murashige, T. \& Skoog, F. 1962. A revised medium for rapid growth and bio assays with tobacco tissue cultures. Physiologia Plantarum 15(3): 473-497.

Pornpienpakdee, P., Singhasurasak, R., Chaiyasap, P., Pichyangkura, R., Bunjongrat, R., Chadchawan, P. \& Limpanavech, P. 2010. Improving the micropropagation efficiency of hybrid Dendrobium orchids with chitosan. Scientia Horticulturae 124(4): 490-499.

Rahman, M., Mukta, J.A., Sabir, A.A., Gupta, D.R., Mohi-UdDin, M., Hasanuzzaman, M., Miah, M.G., Rahman, M. \& Islam, M.T. 2018. Chitosan biopolymer promotes yield and stimulates accumulation of antioxidants in strawberry fruit. PLoS One 13(9): e0203769.

Ramírez-Mosqueda, M.A. \& Iglesias-Andreu, L.G. 2016. Direct organogenesis of Stevia rebaudiana Bertoni using thin cell layer (TCL) method. Sugar Tech 18(4): 424-428.

Samanta, A., Das, G. \& Das, S.K. 2011. Roles of flavonoids in plants. International Journal of Pharmaceutical Sciences and Research 6(1): 12-35.

San José, C., Cernadas, M.J. \& Corredoira, E. 2014. Histology of the regeneration of Paulownia tomentosa (Paulowniaceae) by organogenesis. Rev. Biol. Trop. 62(2): 809-818.

Shukla, S., Mehta, A., Bajpai, V.K. \& Shukla, S. 2009. In vitro antioxidant activity and total phenolic content of ethanolic leaf extract of Stevia rebaudiana Bert. Food Chemical Toxicology 47: 2338-2343.

Singh, S. 2016. Enhancing phytochemical levels, enzymatic and antioxidant activity of spinach leaves by chitosan treatment and an insight into the metabolic pathway using DART-MS technique. Food Chemistry 199: 176-184.

Sivanandhan, G., Dev, G.K., Jeyaraj, M., Rajesh, M., Arjunan, A., Muthuselvam, M., Manickavasagam, M., Selvaraj, N. \& Ganapathi, A. 2013. Increased production of withanolide A, withanone, and withaferin A in hairy root cultures of Withania somnifera (L.) Dunal elicited with methyl jasmonate and salicylic acid. Plant Cell, Tissue and Organ Culture 114(1): 121-129.

Sopalun, K., Thammasiri, K. \& Ishikawa, K. 2010. Effects of chitosan as the growth stimulator for Grammatophyllum speciosum in vitro culture. World Academy of Science, Engineering and Technology 4: 11-29.

Sun, Y., Hou, M., Mur, L.A.J., Yang, Y., Zhang, T., Xu, X., Huang, S. \& Tong, H. 2019. Nitrogen drives plant growth to the detriment of leaf sugar and steviol glycosides metabolisms in Stevia (Stevia rebaudiana Bertoni). Plant Physiology and Biochemistry 141: 240-249.

Suriyaprabha, R., Karunakaran, G., Yuvakkumar, R., Prabu, P., Rajendran, V. \& Kannan, N. 2012. Growth and physiological responses of maize (Zea mays L.) to porous silica nanoparticles in soil. Journal of Nanoparticle Research 14(12): 1294

Tadhani, M.B., Jadeja, R.P. \& Rema, S. 2006. Micropropagation of Stevia rebaudiana using multiple shoot culture. Journal of Cell and Tissue Research 6(1): 545.

Talreja, T. 2011. Biochemical estimation of three primary metabolites from medicinally important plant Moringa oleifera. International Journal of Pharmaceutical Sciences Review Research 7: 186-188.

Thiyagarajan, M. \& Venkatachalam, P. 2012. Large scale in vitro propagation of Stevia rebaudiana (bert) for commercial application: Pharmaceutically important and antidiabetic medicinal herb. Industrial Crops and Products 37: 111-117.

Totté, N., Charon, L., Rohmer, M., Compernolle, F., Baboeuf, I. \& Geuns, J.M. 2000. Biosynthesis of the diterpenoid steviol, an ent-kaurene derivative from Stevia rebaudiana Bertoni, via the methylerythritol phosphate pathway. Tetrahedron Letters 41(33): 6407-6410.

Ummi, N.A.A.R., Ong, C.B., Yu, T.S. \& Lau, L.K. 2014. In vitro micropropagation of Stevia rebaudiana Bertoni in Malaysia. Brazilian Archives of Biology and Technology 57(1): 23-28.

Uthairatanakij, A., Teixeira da Silva, J.A. \& Obsuwan, K. 2007. Chitosan for improving orchid production and quality. Orchid Science and Biotechnology 1(1): 1-5.

Van Handel, E. 1985. Quenching of carbohydrate reactions by azide. Analytical Biochemistry 148(2): 434-435.

Yoneda, Y., Shimizu, H., Nakashima, H., Miyasaka, J. \& Obdoi, K. 2017. Effect of treatment with gibberellin, gebberellin biosynthesis inhibitor, and auxin steviol glycoside content in Stevia rebaudiana Bertoni. Sugar Tech 20(4): 482-491.

Zhang, X., Li, K., Xing, R., Liu, S. \& Li, P. 2017. Metabolite profiling of wheat seedlings induced by chitosan: Revelation of the enhanced carbon and nitrogen metabolism. Frontiers in Plant Science 8: 1-13

Zheng, J., Zhuang, Y., Mao, H.Z. \& Jang, I.C. 2019. Overexpression of SrDXS1 and $\operatorname{Sr} K A H$ enhances steviol glycosides content in transgenic Stevia plants. BMC Plant Biology 19(1): 1-16.

Zou, P., Li, K., Liu, S., Xing, R., Qin, Y., Yu, H., Zhou, M. \& Li, P. 2015. Effect of chitooligosaccharides with different degrees of acetylation on wheat seedlings under salt stress. Carbohydrate Polymers 126: 62-69.

Chu-Nie Tang, Dhilia Udie Lamasudin, Wan Muhamad Asrul Nizam Wan Abdullah, Chew-Li Moo, Miao-Si Chiew, Qian-Yee Chai \& Janna Ong-Abdullah

Department of Cell and Molecular Biology

Faculty of Biotechnology and Biomolecular Sciences

Universiti Putra Malaysia

43400 UPM Serdang, Selangor Darul Ehsan

Malaysia 
Kok-Song Lai*

Health Sciences Division

Abu Dhabi Women's College

Higher Colleges of Technology

41012 Abu Dhabi

United Arab Emirates
*Corresponding author; email: 1koksong@hct.ac.ae

Received: 5 September 2019

Accepted: 13 August 2020 